\title{
The IL-10 polarized cytokine pattern in innate and adaptive immunity cells contribute to the development of FVIII inhibitors
}

\author{
Amanda CO Silveira ${ }^{1 * \dagger}$, Marcio AP Santana ${ }^{2 \dagger}$, Isabella G Ribeiro ${ }^{1,2+}$, Daniel G Chaves $^{2 \dagger}$ and Olindo A Martins-Filho ${ }^{1+}$
}

\begin{abstract}
Background: Hemophilia A (HA) is an X-linked inherited bleeding disorder, resulting from a qualitative or quantitative deficiency of clotting factor VIII (FVIII). Antibodies against FVIII, also called inhibitors, block the procoagulant activity of FVIII; thus, impairing hemostatic activity in patients with HA. The exact mechanism underlying the immunological events behind the development of inhibitors remains unknown. This study aimed to understand immune response to FVIII in patients with HA who were either positive [HAa-FVIII(+)] or negative [HAa-FVIII(-)] for inhibitors.

Methods: Cytokine profiles [interferon- $\gamma$ (IFN - $\gamma$ ), tumor necrosis factor- $a$ (TNF-a), interleukin-4 (IL-4), IL-5, and IL-10] of innate and adaptive immune cells present in the peripheral blood of participants were characterized.

Results: Presence of inhibitors was significantly associated with decreased frequencies of TNF-a-positive monocytes and neutrophils, IL-5-positive monocytes, IL-4-positive neutrophils, and increased frequencies of IL-10-positive neutrophils and T cells. T cells from HAa-FVIII(-) patients expressed increased levels of almost all cytokines. In contrast, HAa-FVIII(+) patients showed lower levels of all cytokines in $\mathrm{CD}^{+}$and $\mathrm{CD}^{+} \mathrm{T}$ cells, except IL-10. B cells from HAa-FVIII(-) patients expressed increased levels of IL-4 while those from HAa-FVIII(+) patients expressed increased levels of IL-10.
\end{abstract}

Conclusions: The global cytokine profiles of innate and adaptive immune cells showed an anti-inflammatory/regulatory pattern in $\mathrm{HAa}-\mathrm{FVIII}(+)$ patients and a mixed pattern, with a bias toward inflammatory cytokine profile, in HAa-FVIII(-) patients. The occurrence of these profiles seems to be associated with presence FVIII inhibitors.

Keywords: Immune regulation, Intracellular cytokine staining, Cytokine profile, FVIII inhibitors, Hemophilia A

\section{Background}

Hemophilia A (HA) is an X-linked inherited bleeding disorder resulting from a qualitative or quantitative deficiency of clotting factor VIII (FVIII) [1]. HA is classified as mild, moderate, or severe based on the degree of FVIII residual activity [2]. Treatment of patients with HA involves replacement therapy with plasma-derived FVIII (pdFVIII) or recombinant FVIII [3]. A major clinical complication observed during replacement therapy is the development of antibodies against FVIII (called inhibitors) that block its procoagulant activity. Approximately 10\%$15 \%$ patients with $\mathrm{HA}$ and $25 \%-30 \%$ patients with severe

\footnotetext{
* Correspondence: amandacardoso@cpqrr.fiocruz.br

${ }^{\dagger}$ Equal contributors

'Laboratório de Biomarcadores de Diagnóstico e Monitoração, Centro de Pesquisas René Rachou, FIOCRUZ/MG, Belo Horizonte, Minas Gerais, Brazil Full list of author information is available at the end of the article
}

HA develop inhibitors [4]. Patient's age at the time of the first exposure to replacement therapy and type and frequency of FVIII exposure are risk factors for inhibitor formation; in addition, mutations in the gene encoding FVIII and variations in the immune system are important risk factors for inhibitor formation [5]. Anti-FVIII antibodies are immunoglobulin G (IgG) antibodies, mainly IgG4; in some cases, IgG1 and IgG2 can also be detected [6,7].

Type 1 cells have been established to play a role in the initial immune response to FVIII, and type 2 cells act in the development of strong inhibitor production. $\mathrm{CD} 4^{+} \mathrm{T}$ cells are important for the production of inhibitors because they secrete both proinflammatory and antiinflammatory/regulatory cytokines [8]. Studies have described that polymorphisms in genes encoding cytokines such as TNF- $\alpha$ and IL-10 greatly affect inhibitor 
production [5,9-11]. Several studies have focused on immune response in patients with $\mathrm{HA}$ to elucidate the mechanisms underlying inhibitor production. We observed that the global cytokine profiles of innate and adaptive immune cells showed a major anti-inflammatory/ regulatory pattern in patients with $\mathrm{HA}$ who were positive for inhibitors [HA $\alpha$-FVIII $(+)]$ and showed a mixed pattern, with a bias toward an inflammatory cytokine profile, in patients who were negative for inhibitors $[\mathrm{HA} \alpha-\mathrm{FVIII}(-)]$. In addition, we proposed that these cytokine profile patterns may be the key elements in the production of distinct subclasses of anti-FVIII antibodies [12-14]. To understand immune response to FVIII, we characterized the cytokine patterns of peripheral blood leukocytes from whole blood samples of healthy blood donors, HA $\alpha-F V I I I(+)$ patients, and HA $\alpha-F V I I I(-)$ patients. In addition, we examined the differential synthesis of proinflammatory (IFN- $\gamma$ and TNF- $\alpha$ ) and anti-inflammatory/ regulatory (IL-4, IL-5, and IL-10) cytokines in innate (neutrophils and monocytes) and adaptive (CD4 $4^{+}$and $\mathrm{CD}^{+} \mathrm{T}$ and B cells) immune cells.

\section{Methods}

Study population and sample collection

This case-control study included 85 subjects who were classified into three groups: (1) healthy blood donors (BDs; $n=30$; mean age, $31.6 \pm 12.8$ years), (2) patients with HA without history of inhibitors (HA $\alpha$-FVIII(-); $n=30$; mean age, $27.6 \pm 16.6$ years), and (3) patients with HA who had inhibitors (HA $\alpha$-FVIII $(+) ; n=25$; mean age, $21.9 \pm 13.8$ years; mean anti-FVIII inhibitor level at the time of blood collection, $11.0 \mathrm{UB} / \mathrm{mL}$ ). All the patients received on-demand (episodic) treatment and were paired by gender and age. Table 1 summarizes the main characteristics of HA $\alpha-\mathrm{FVIII}(+)$ patients. Heparinized blood samples from all the subjects were collected in vacutainer tubes (BD Pharmingen, San Diego, CA, USA). All the study subjects visited Fundação Hemominas, Minas Gerais, Brazil. This study was approved by the ethics committee of the Hemominas Foundation and by the National Commission of Ethics in Research, Brazil. Written informed consent for participation in the study was obtained from participants or their parent or

Table 1 Characterization of patients with HA who were positive for inhibitors

\begin{tabular}{|c|c|c|c|c|c|}
\hline Patient number & Age (years) & Level of circulating FVIII & Severity & $\begin{array}{l}\text { Historical peak of } \\
\text { Bethesda titer (UB/mL) }\end{array}$ & $\begin{array}{l}\text { Bethesda titer (UB/mL) at the } \\
\text { time of blood collection }\end{array}$ \\
\hline 1 & 11 & 2.0 & Moderate & 16.0 & 16.0 \\
\hline 2 & 19 & $<1.0$ & Severe & 3.2 & 0.0 \\
\hline 3 & 35 & $<1.0$ & Severe & 384.0 & 20.8 \\
\hline 4 & 11 & 2.7 & Moderate & 12.8 & 8.4 \\
\hline 5 & 14 & $<1.0$ & Severe & 192.0 & 20.8 \\
\hline 6 & 13 & 1.9 & Moderate & 5.8 & 5.8 \\
\hline 7 & 40 & $<1.0$ & Severe & 93.0 & 16.0 \\
\hline 8 & 19 & $<1.0$ & Severe & 160.0 & 12.0 \\
\hline 9 & 27 & $<1.0$ & Severe & 5.4 & 5.4 \\
\hline 10 & 6 & 4.0 & Moderate & 14.4 & 6.4 \\
\hline 11 & 37 & 1.8 & Moderate & 128.0 & 0.6 \\
\hline 12 & 22 & $<1.0$ & Severe & 288.0 & 115.2 \\
\hline 13 & 31 & $<1,0$ & Severe & 25.6 & 14.4 \\
\hline 14 & 14 & 2.9 & Moderate & 36.0 & 5,2 \\
\hline 15 & 8 & 1.0 & Severe & 384.0 & 4.6 \\
\hline 16 & 16 & $<1.0$ & Severe & 7.0 & 2.8 \\
\hline 17 & 38 & $<1.0$ & Severe & 48.0 & 0.3 \\
\hline 18 & 8 & 2.8 & Moderate & 768.0 & 2.0 \\
\hline 19 & 10 & 1.0 & Severe & 48.0 & 1.2 \\
\hline 20 & 36 & 1.5 & Moderate & 13.0 & 0.0 \\
\hline 21 & 14 & $<1.0$ & Severe & 52.0 & 13.2 \\
\hline 22 & 39 & $<1.0$ & Severe & 3.9 & 0.0 \\
\hline 23 & 1 & 1.6 & Moderate & 6.6 & 0.5 \\
\hline 24 & 23 & $<1.0$ & Severe & 224.0 & 1.4 \\
\hline 25 & 57 & $<1.0$ & Severe & 20.8 & 1.0 \\
\hline
\end{tabular}


their guardian where applicable. Patients with HA are frequently examined at the Fundação Hemominas to determine the presence of inhibitors. HA $\alpha$-FVIII(+) patients were selected based on their positive history of inhibitors. Median time between the first inhibitor production and the time of sampling was 170.8 months (range, 10.9241.0 months). Any results above $0.6 \mathrm{UB} / \mathrm{mL}$ were considered positive for the presence of inhibitors. Patients were selected by carefully analyzing their medical records. Individuals with a history of transient inhibitor production were excluded from the study. All patients with HA did not receive FVIII infusions for 30 days before the date of blood collection to avoid any influence due to a new exposure. Bethesda titer of HA $\alpha$-FVIII(-) patients was monitored for two months after FVIII exposure to verify the production of inhibitors. Patients with human immunodeficiency virus and hepatitis $C$ virus infections and individuals with apparent infections or inflammatory processes were excluded from the study. For all patients, the Bethesda titer was confirmed in a second sample.

\section{Immunophenotyping of cell subsets and intracellular cytokines}

Peripheral blood cells were immunostained in the dark for $30 \mathrm{~min}$ at room temperature with TriColor-labelled [TCphycoerythrin (PE)-cyanin 5 (Cy5)] monoclonal antibodies (mAbs) (Caltag, Burlingame, CA, USA), including antiCD4 (clone S3.5), anti-CD8 (clone M-L233), anti-CD14 (clone TüK4), anti-CD16 (clone 3G8), and anti-CD19 (clone 4G7) mAbs. After lysis/fixation, the leukocytes were permeabilized by incubation with phosphate-buffered saline (PBS) permeabilization reagent (PBS supplemented with $0.5 \%[\mathrm{w} / \mathrm{v}$ ] saponin [Sigma, St Louis, MO, USA]) for $10 \mathrm{~min}$ at room temperature. Fixed/Permeabilized cells were then incubated in the dark for $30 \mathrm{~min}$ at room temperature with $20 \mu \mathrm{L}$ PE-labeled anti-cytokine mAbs (IFN- $\gamma$, clone B27; TNF- $\alpha$, clone MAB11; IL-4, clone MP4-25D2; IL-5, clone TRFK5; and IL-10, JES3-9D7 [e-Bioscience, San Diego, CA, USA]) in PBS permeabilization reagent.

\section{Flow cytometry acquisition and analysis}

After immunophenotyping, leukocyte suspensions were run in a FACScalibur flow cytometer (Becton Dickinson, San Jose, CA, USA) to collect 30,000 ungated events per sample. The acquired data were analyzed using CellQuest software (Franklin Lakes, NJ, USA). Distinct gating strategies were used to analyze cytokine-expressing leukocyte subpopulations from innate and adaptive immune cells. Neutrophils were selected as $\mathrm{SSC}^{\mathrm{High}} \mathrm{CD} 16^{\mathrm{High+}}$ cells and monocytes were selected as CD14 ${ }^{\text {High+ }}$ cells on FL3/ anti-CD16-TC and FL3/anti-CD14-TC versus laser side-scatter (SSC) dot plots, respectively. Lymphocyte populations were first selected on laser forward-scatter
(FSC) versus SSC dot plots. The number of gated neutrophils, monocytes, and lymphocytes ranged from 19,500 to $22,500,1,200$ to 2,100 , and 6,000 to 9,000 , respectively. After the initial gate selection, the frequencies of cytokine-positive cells were quantified using quadrant statistics applied on FL3/anti-cell surface marker-TC versus FL2/anti-cytokine-PE dot plots. PECy5-labeled antibodies were detected on FL3 channel, and PE-labeled antibodies were detected on FL2 channel. Distinct tubes were used to evaluate the percentage of cytokine-positive $\mathrm{T}$ cells $\left(\mathrm{CD}^{+}\right.$and $\left.\mathrm{CD} 8^{+}\right)$and $\mathrm{B}$ cells $\left(\mathrm{CD} 19^{+}\right)$. Data were expressed as the percentage of cytokine-positive cells among gated neutrophils, monocytes, and total lymphocytes. The results were assembled further to calculate the global cytokine profiles of immune cells, as proposed earlier [12]. Briefly, the median percentage for each cytokine-positive cell population was calculated using the values obtained for each study group [BD, HA $\alpha-$ FVIII(-), and HA $\alpha-$ FVIII(+) groups].

\section{Statistical analysis}

Statistical analyses were performed using GraphPad Prism 5 software (San Diego, CA, USA). Because all data files assumed a non-Gaussian distribution, statistical comparisons were performed using non-parametric Kruskal-Wallis test followed by Dunn's multiple comparison test to evaluate cytokine profiles of innate and adaptive immune cells from BDs, HA $\alpha-F V I I I(-)$ patients, and HA $\alpha-F V I I I(+)$ patients. Differences were considered significant when $\mathrm{p}$-values were $<0.05$.

\section{Results}

Monocytes and neutrophils from $\mathrm{HA} \alpha-\mathrm{FVIII}(+)$ patients have an anti-inflammatory/regulatory cytokine profile Analysis of monocytes showed significantly lower frequencies of TNF- $\alpha$-positive and IL-5-positive cells in HA $\alpha$ FVIII(+) patients than in HA $\alpha-F V I I I(-)$ patients and BDs. The analyses also showed considerable frequencies of monocytes with a high production of TNF- $\alpha$ in HA $\alpha$-FVIII(-) group when compared to the BD group. All the three groups had similar frequencies of IL-4-positive and IL-10-positive monocytes. Analysis of neutrophils showed lower frequency of TNF- $\alpha$-positive cells in HA $\alpha$-FVIII(+) patients than in HA $\alpha$-FVIII(-) patients and BDs. Conversely, higher frequencies of IL-10-positive neutrophils were observed in HA $\alpha$-FVIII $(+)$ patients than in HA $\alpha$-FVIII(-) patients and BDs. Moreover, lower frequencies of IL-4-positive neutrophils were observed in HA $\alpha$ FVIII(+) patients than in HA $\alpha-F V I I I(-)$ patients. However, the three groups showed similar frequencies of IL-5positive neutrophils (Figure 1). 


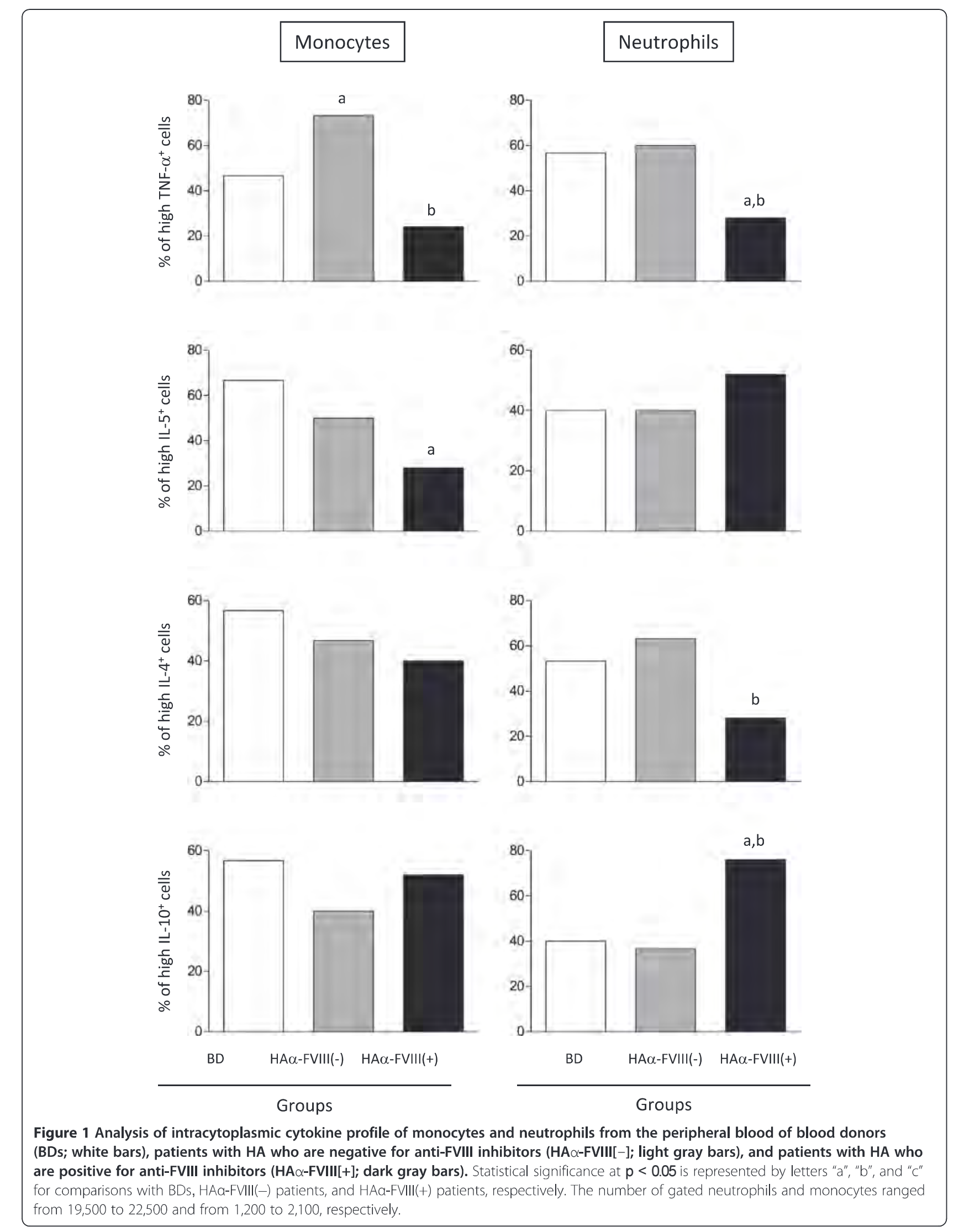


High synthesis of IL-10 is the hallmark of CD4 ${ }^{+}$and $\mathrm{CD}^{+}$ T cells in $\mathrm{HA} \alpha-\mathrm{FVIII}(+)$ patients

Immunophenotyping of adaptive immune cells showed that $\mathrm{T}$ cells $\left(\mathrm{CD}^{+}\right.$and $\left.\mathrm{CD}^{+}\right)$of BDs had basal levels of all the analyzed cytokines. Furthermore, T cells of HA $\alpha-$ FVIII(-) patients had significantly elevated levels of all the cytokines, except IL-10. However, T cells of HA $\alpha-F V I I I(+)$ patients only had elevated levels of IL-10 (Figure 2).

\section{B cells from patients with HA and BDs have similar cytokine profiles}

Analysis of B cells showed higher levels of IL-4-positive cells in HA $\alpha$-FVIII(-) patients than in BDs. In addition, higher frequency of IL-10-positive B cells was observed in HA $\mathrm{H}-\mathrm{FVIII}(+)$ patients than in BDs. However, the three groups showed similar frequencies of TNF- $\alpha-$ positive and IL-5-positive B cells (Figure 3).

\section{Discussion}

The treatment regimen of FVIII varies among different countries and among centers in the same country. For patients included in this study, on-demand treatment was used to manage clinically evident bleeding. FVIII replacement therapy depends on age, severity, and treatment regimen. Recent studies have shown that median annual on-demand FVIII utilization (IU $\mathrm{kg}^{-1} \cdot$ year $^{-1}$ ) varies between 1,100 and $1,429 \mathrm{IU} \mathrm{kg}^{-1} \cdot$ year $^{-1}[13,14]$. Our data showed that patients receiving on-demand treatment at Fundação Hemominas used 1,452 IU kg-1 year $^{-1}$ of FVIII. Recent reports have shown that replacement therapy with these amounts of FVIII products can cause several changes in the immune profile of patients with HA [15-19].

Production of anti-FVIII inhibitors remains a challenge in the treatment of patients with HA. Therefore, understanding the cellular compartmentalization of immune responses is important. Little is known about the cytokine profiles and cell types implicated in auto- and alloimmune responses to FVIII. Previous studies have shown that patients with HA who are positive for inhibitors have a major anti-inflammatory/regulatory immune cytokine profile while those without inhibitors have a mixed pattern, with a bias toward an inflammatory cytokine profile. These findings support and suggest that proinflammatorymodulated immune response may favor the synthesis of anti-FVIII IgG1 antibodies and prevent the synthesis of anti-FVIII IgG4 inhibitors [12,20,21]. It has been suggested that immunological context along with the intensity of treatment favors the class switching of FVIII-specific antibodies to IgG4 [22].

The findings of the present study highlight the significantly lower frequencies of TNF- $\alpha$-positive monocytes and neutrophils, IL-5-positive monocytes, and IL-4-

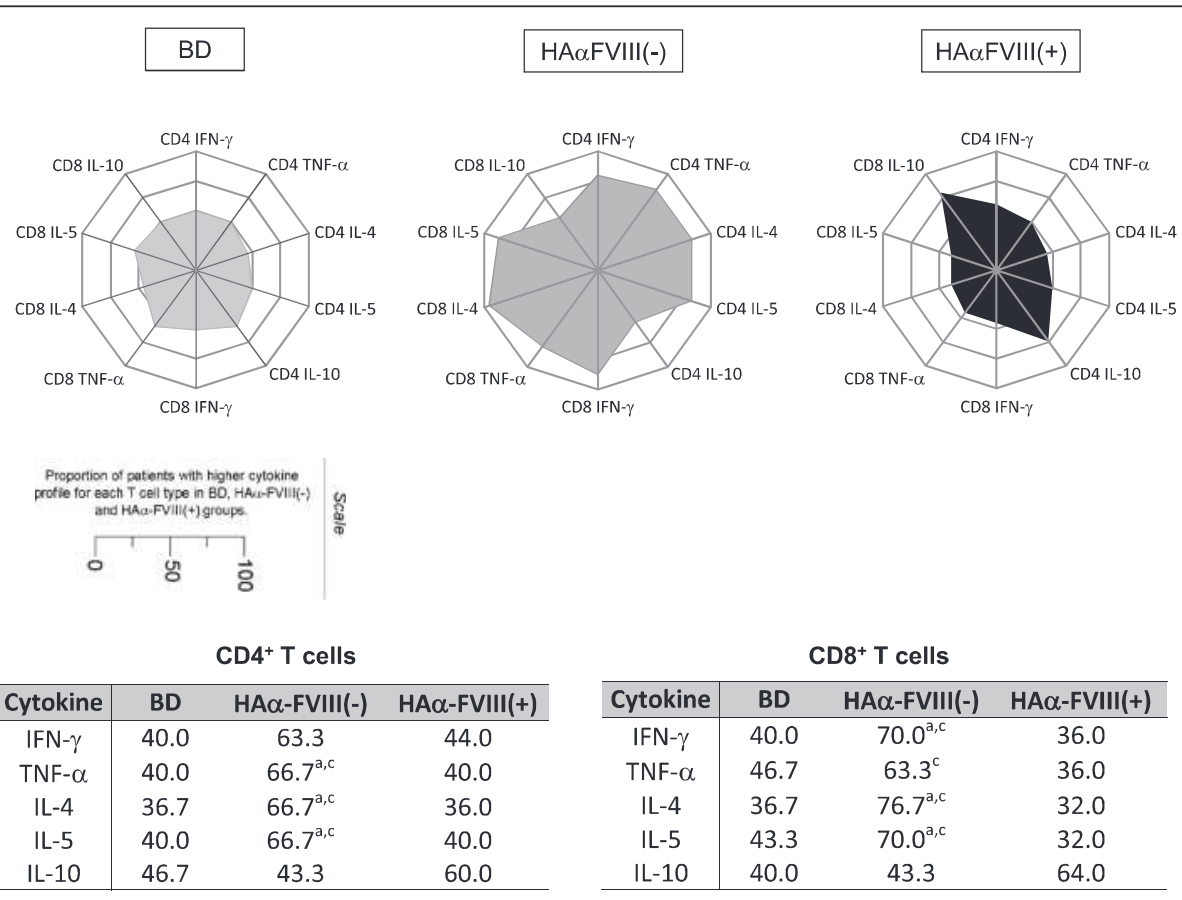

Figure 2 Overall proinflammatory and anti-inflammatory/regulatory cytokine patterns of lymphocytes. (a) Radar chart summarizes the percentage of proinflammatory and anti-inflammatory/regulatory cytokine balance in adaptive immune cells from BDs (light gray area), HAa-FVIII(-) patients (dark gray area), and HAa-FVIII(+) patients (black area). Each axis displays the proportion of each cytokine balance category within a given leukocyte subset. (b) Median percentage of each cytokine T cell population studied for groups BD, HAa-FVIII(-) and HAa-FVIII(+). Statistical significance at $\mathbf{p}<0.05$ is represented by letters " $a$ ", "b", and " $c$ " for comparisons with BDs, HAa-FVIII(-) patients, and HAa-FVII(+) patients, respectively. 

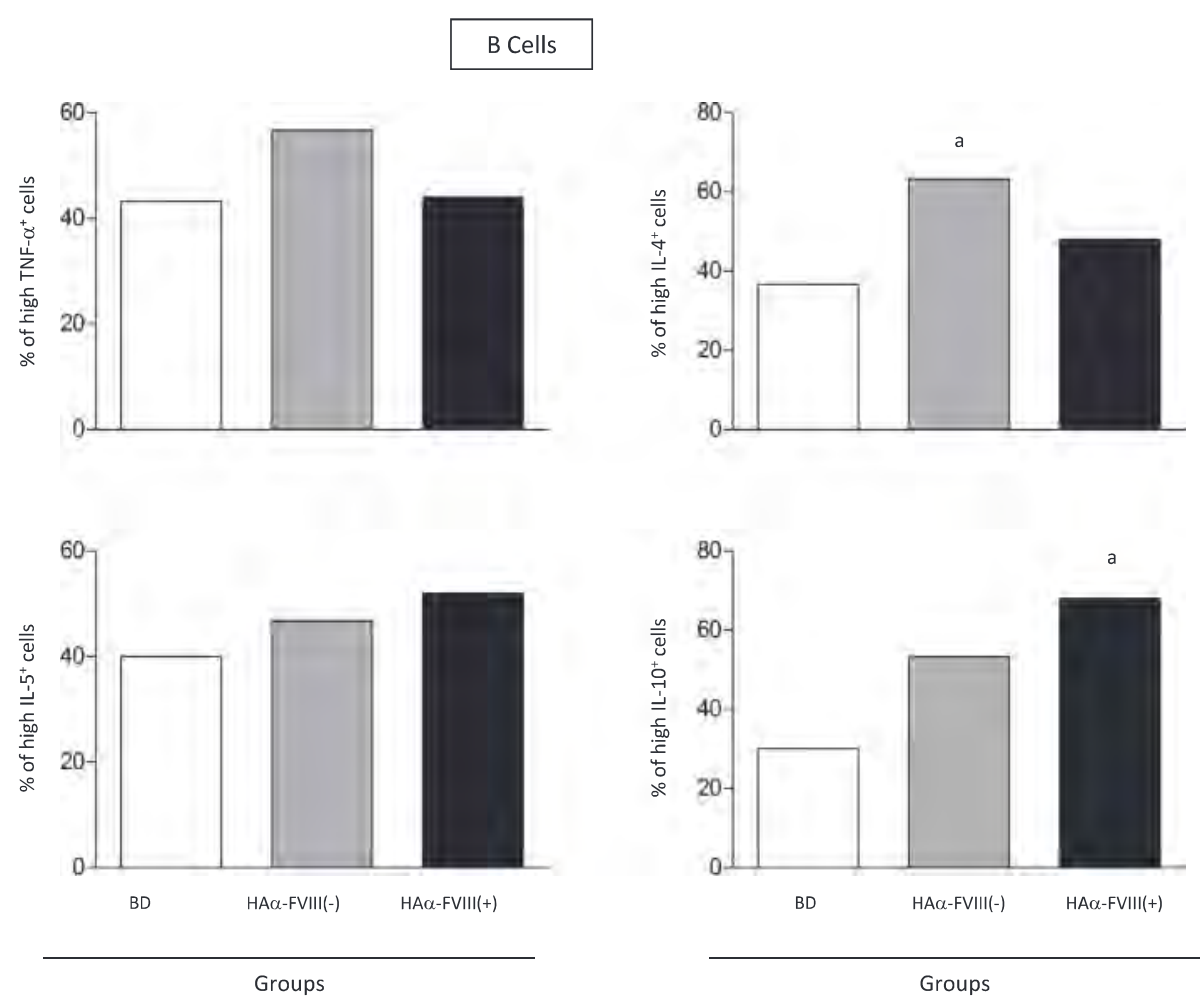

Figure 3 Percentage of TNF- $\alpha$-positive, IL-5-positive, IL-4-positive, and IL-10-positive B cells from the peripheral blood of BDs (white bars), $\mathrm{HA} \alpha-\mathrm{FVIII}(-)$ patients (light gray bars), and HA $\alpha-\mathrm{FVIII}(+)$ patients (dark gray bars). Statistical significance at $\mathrm{p}<0.05$ is represented by letters "a"', "b" and "c" for comparisons with BDs, HAa-FVIII(-) patients, and HAa-FVIII(+) patients, respectively.

positive neutrophils and higher frequencies of IL-10positive neutrophils in $\mathrm{HA} \alpha-\mathrm{FVIII}(+)$ patients. Recent studies have shown that neutrophils not only synthesize cytokines in response to various inflammatory stimuli in chronic inflammatory disorders (such as rheumatoid arthritis, inflammatory bowel diseases, diabetes, and mycobacterial infections) but also regulate immune responses such as those suggested in HA. Some studies have also proposed that the cytokine profile of neutrophils is similar to the cytokine profiles of monocytes and macrophages. Therefore, modulation of cytokines derived from monocytes and neutrophils is a potentially useful strategy for therapeutic immunointervention [23-25].

Stimulation of B cells to produce FVIII inhibitors is dependent on $\mathrm{CD}_{4}^{+} \mathrm{T}$ [26]. However, recent reports describe the contribution of $\mathrm{CD}^{+} \mathrm{T}$ cells in this context. A recent study has shown an association between $\mathrm{CD}^{+} \mathrm{T}$ cells and induction of immune tolerance. It was found that human $\mathrm{CD}^{+} \mathrm{T}$ cells also functioned as regulatory $\mathrm{T}$ cells to induce immune tolerance by suppressing activated $\mathrm{T}$ cells through IL-10 production [27-29]. In addition, CD8 ${ }^{+}$ cytotoxic cells mediate the apoptosis of $\mathrm{T}$ cells that contribute to peripheral tolerance [30]. Proliferation of $\mathrm{CD} 8^{+}$ suppressor cells and activated $\mathrm{CD}^{+} \mathrm{T}$ cells is observed in patients with HA; moreover, proliferation of suppressor cells seems to be mainly related to FVIII infusion [31]. These regulatory $\mathrm{T}$ cells are important for regulating other $\mathrm{T}$ cells without the intervention of antigen-presenting cells (APCs). In addition, it is well known that repeated infusions of pdFVIII concentrates skews TCR repertoires for $\mathrm{CD}^{+} \mathrm{T}$ cells $[15,19]$.

Analysis of T cells from HA $\alpha$-FVIII(-) patients showed elevated levels of almost all cytokines. In contrast, $\mathrm{T}$ cells

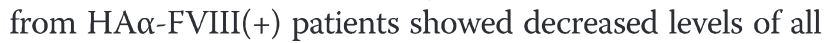
the tested cytokines, except IL-10. The immune response against FVIII develops as a classical $\mathrm{T}$ cell-dependent antibody-mediated immune response. Infused FVIII is recognized, internalized, and processed by APCs and is presented to antigen-specific $\mathrm{CD} 4^{+} \mathrm{T}$ cells that provide activation signals to antigen-specific B cells, thus resulting in the synthesis of anti-FVIII antibodies and long-lived FVIIIspecific memory B cells $[8,32,33]$. The data obtained in this study showed that the cytokine microenvironment promoted by $\mathrm{T}$ cells is determinant for the presence or absence of FVIII inhibitors. These data are consistent with those of different studies that observed a mixed cytokine pattern, with a bias toward an inflammatory cytokine profile, in HA $\alpha$-FVIII(-) patients and anti-inflammatory/ regulatory pattern in $\mathrm{HA} \alpha-\mathrm{FVIII}(+)$ patients $[7,8,12,34]$. The changes observed in $\mathrm{CD}^{+} \mathrm{T}$ cell compartment also 
seem to be related to the production of inhibitors and the regulatory profiles of these cells. In HA $\alpha$-FVIII(-) patients, increased cytokine production by lymphocytes contributed to the prevention of inhibitor production by modulation of the immune system; in contrast, in the inhibitor-positive patients, reducing the production of cytokines inducing immune microenvironment modifying the expansion of lymphocytes with a regular profile, increasing the production of IL-10 in order to re-modulate the immune system; However, other changes, which need investigation, prevent this process, thus resulting in the production of inhibitors.

Analysis of B cells showed that HA $\alpha$-FVIII(-) patients had higher levels of IL-4-positive B cells and HA $\alpha$-FVIII(+) patients had higher levels of IL-10-positive B cells. Because of their central role in inhibitor production, it is important to elucidate the cytokine profile of B cells in patients with HA. The IL-10-predominant cytokine profile of B cells observed in this study is well characterized as a downregulator of TNF- $\alpha$, IL- $1 \alpha$, and IL- $1 \beta$ production. However, it stimulates $\mathrm{B}$ cell proliferation and differentiation and antibody production [35]. Importantly, B cells are not merely antibody producers but actively contribute by regulating immune response and secreting cytokines that amplify humoral and cellular immune responses [36-39].

\section{Conclusions}

Typically, various cytokines and chemokines act as mediators in an immune response. It is important to note that genes encoding IL-10 and TNF- $\alpha$ were the first genes located outside the gene encoding FVIII to be associated with inhibitor production in patients with HA [9-11,40]. However, different risk factors such as ethnicity, type of mutation in the gene encoding FVIII, family history of inhibitor production, type of FVIII (plasmatic or recombinant) therapy, patient age at the time of first exposure to replacement therapy, initial doses of FVIII concentrate, mode of infusion, surgery, intensity of treatment or regular prophylaxis, and inflammatory state or HLA haplotype of patients are associated with inhibitor production and should be investigated further. Other causes of inhibitor production against FVIII include stress, age, malignancy, coinfections, pregnancy, and antibiotics [41-43]. Based on these findings, we hypothesize that antiinflammatory/regulatory cytokine-dominant microenvironment determined by monocytes, neutrophils, $\mathrm{T}$ cells, and B cells may favor the synthesis of anti-FVIII IgG4 with inhibitory activity. In addition, the proinflammatory microenvironment corroborates with the synthesis of antiFVIII IgG1 non-inhibitory antibody [12,20,21].

The limitations of the study include limited number of patients and absence of information on mutations in the gene encoding FVIII. An important issue to be considered in future investigations is to analyze the kinetic conversion of a proinflammatory immune response to an anti- inflammatory/regulatory immune response against FVIII in HA $\alpha-F V I I I(+)$ patients and the risk factors that may be associated with this conversion during HA treatment. The anti-inflammatory/regulatory cytokine profile of innate immune cells in patients with HA could be an important biomarker for the development of high inhibitor titers [7].

\section{Competing interests}

The authors declare that they have no competing interests.

\section{Authors' contributions}

ACOS carried out the immunoassays, analysis and interpretation of data and drafted the manuscript. MAPS conducted the follow-up of patients. IGR carried out the immunoassays DGC participated in the design of the study, carried out the immunoassays, analysis and interpretation of data, drafted the manuscript and performed the statistical analysis. OAMF conceived and coordinated the study. All authors read and approved the final version of the manuscript.

\section{Acknowledgements}

We thank the Fundação de Amparo à Pesquisa do Estado de Minas Gerais (FAPEMIG) financial support. O.A.M.F. is thankful to Conselho Nacional de Desenvolvimento Científico e Tecnológico (CNPq) for the research fellowship $(\mathrm{PQ})$ and D.G.C. acknowledges the FAPEMIG for the BIP fellowship programme.

\section{Author details}

${ }^{1}$ Laboratório de Biomarcadores de Diagnóstico e Monitoração, Centro de Pesquisas René Rachou, FIOCRUZ/MG, Belo Horizonte, Minas Gerais, Brazil. ${ }^{2}$ Serviço de Pesquisa, Fundação Hemominas, Belo Horizonte, Minas Gerais, Brazil.

Received: 24 June 2014 Accepted: 8 December 2014

Published online: 16 January 2015

\section{References}

1. Davie EW, Fujikawa K, Kisiel W. The coagulation cascade: initiation, maintenance, and regulation. Biochemistry. 1991;30 Suppl 43:10363-70.

2. Fischer $K$, Van Den Berg M. Prophylaxis for severe haemophilia: clinical and economical issues. Haemophilia. 2003;9 Suppl 4:376-81.

3. Spiegel PCJ, Stoddard BL. Optimization of factor VIII replacement therapy: Can structural studies help in evading antibody inhibitors? Br J Haematol. 2002;119 Suppl 2:310-22.

4. Wight J, Paisley S. The epidemiology of inhibitors in haemophilia A: a systematic review. Haemophilia. 2003;9 Suppl 4:418-35.

5. Agostini D, Rosset C, Botton MR, Kappel DB, Vieira IA, Gorziza RP, et al. Immune system polymorphisms and factor VIII inhibitor formation in Brazilian haemophilia A severe patients. Haemophilia. 2012;18 Suppl 6:416-8.

6. Lollar P. Pathogenic antibodies to coagulation factors. Part one: factor VIII and factor IX. J Thromb Haemost. 2004;2 Suppl 7:1082-95.

7. Reding MT, Lei S, Lei H, Green D, Gill J, Conti-Fine BM. Distribution of Th1and Th2-induced anti-factor VIII lgG subclasses in congenital and acquired haemophilia patients. Thromb Haemost. 2002;88 Suppl 4:568-75.

8. Hu G, Guo D, Key NS, Conti-Fine BM. Cytokine production by CD4+ T cells specific for coagulation factor VIII in healthy subjects and haemophilia A patients. Thrombd Haemost. 2007;97 Suppl 5:788-94.

9. Astermark J, Oldenburg J, Carlson J, Pavlova A, Kavakli K, Berntorp E, et al. Polymorphisms in the TNFA gene and the risk of inhibitor development in patients with hemophilia A. Blood. 2006;108 Suppl 12:3739-45.

10. Astermark J, Oldenburg J, Pavlova A, Berntorp E, Lefvert AK, Mibs Study Group. Polymorphisms in the IL 10 but not in the IL 1 beta and IL4 genes are associated with inhibitor development in patients with hemophilia A. Blood. 2006;107 Suppl 8:3167-72.

11. Chaves DG, Belisario AR, Castro G, Santoro MM, Velloso-Rodrigues C. Analysis of cytokine genes polymorphism as markers for inhibitor development in haemophilia A. Int J Immunogenet. 2010;37 Suppl 2:79-82.

12. Chaves DG, Velloso-Rodrigues C, Oliveira CA, Santoro MM, Martins-Filho AO. A shift towards a T cell cytokine deficiency along with an anti-inflammatory/ regulatory microenvironment may enable the synthesis of anti-FVIII inhibitors in haemophilia A patients. Clin Exp Immunol. 2010;162 Suppl 3:425-37. 
13. Nerich $V$, Tissot E, Faradji A, Demesmay $K$, Bertrand MA, Lorenzini $J$, et al. Cost-of-illness study of severe haemophilia A and B in five French haemophilia treatment centres. Pharm World Sci. 2008;30:287-92.

14. Epstein J, Xiong Y, Woo P, Li-Mcleod J, Spotts G. Retrospective analysis of differences in annual factor VIII utilization among haemophilia A patients. Haemophilia. 2012;18:187-92.

15. Matsutani $T$, Sakurai $Y$, Yoshioka $T$, Tsuruta $Y$, Suzuki $R$, Shima $M$, et al. Replacement therapy with plasma-derived factor VIII concentrates induces skew in T-cell receptor usage and clonal expansion of CD8+ T-cell in HIV-seronegative hemophilia patients. Thromb Haemost. 2003;90:279-92.

16. Gouw SC, Van Den Berg HM, Le Cessie S, Van Der Bom JG. Treatment characteristics and the risk of inhibitor development: a multicenter cohort study among previously untreated patients with severe hemophilia A. J Thromb Haemost. 2007;5:1383-90.

17. Gouw SC, Van Der Bom J, Van Den Berg HM. Treatment-related risk factors of inhibitor development in previously untreated patients with hemophilia A: the CANAL cohort study. Blood. 2007;109 Suppl 11:4648-54.

18. Van Helden PMW, Van Haren SD, Fijnvandraat $K$, Van Den Berg HM, Voorberg J. Factor VIII-specific B cell responses in haemophilia A patients with inhibitors. Haemophilia. 2010:16:35-43.

19. Sakurai Y, Matsutani T, Yoshioka T, Takeda T, Yoshioka A, Shima M. Alterations of $T$ cell receptor $V B$ repertoire of CD8 T lymphocytes in immune tolerance induction in two hemophilia A patients with inhibitors. Vojnosanit Pregl. 2011;68 Suppl 12:1047-50

20. Oliveira CA, Velloso-Rodrigues C, Machado FC, Carvalho BN, Gentz SH, Martins-Filho OA, et al. Cytokine profile and FVIII inhibitors development in haemophilia A. Haemophilia. 2013;19 Suppl 3:139-42

21. Pimentel JP, Chaves DG, Araújo AR, de Araújo EM, da Silva F, Neves WL, et al. Anti-inflammatory/regulatory cytokine microenvironment mediated by IL-4 and IL-10 coordinates the immune response in hemophilia A patients infected chronically with hepatitis C virus. J Med Virol. 2013;85 Suppl 6:1009-18.

22. Van Helden PMW, Van Den Berg HM, Gouw SC, Kaijen PH, Zuurveld MG, Mauser-Bunschoten EP, et al. IgG subclasses of anti-FVIII antibodies during immune tolerance induction in patients with hemophilia A. Br J Haematol. 2008;142 Suppl 4:644-52.

23. Kasama T, Miwa Y, Isozaki T, Odai T, Adachi M, Kunkel SL. Neutrophil-derived cytokines: potential therapeutic targets in inflammation. Curr Drug Targets Inflamm Allergy. 2005:4 Suppl 3:273-9.

24. Hatanaka E, Monteagudo PT, Marrocos MS, Campa A. Neutrophils and monocytes as potentially important sources of proinflammatory cytokines in diabetes. Clin Exp Immunol. 2006;146 Suppl 3:443-7.

25. Wright HL, Moots RJ, Bucknall RC, Edwards RC. Neutrophil function in inflammation and inflammatory diseases. Rheumatology (Oxford). 2010;49 Suppl 9:1618-31.

26. Wroblewska A, Reipert BM, Pratt KP, Voorberg J. Dangerous liaisons: how the immune system deals with factor VIII. J Thromb Haemost. 2013:11:47-55.

27. Le Gal FA, Riteau B, Sedlik C, Khalil-Daher I, Menier C, Dausset J, et al. HLA-G-mediated inhibition of antigen-specific cytotoxic T lymphocytes. Int Immunol. 1999:11:1351-6.

28. Endharti AT, Rifa'l M, Shi Z, Fukuoka Y, Nakahara Y, Kawamoto Y, et al. Cutting Edge: CD8CD122 Regulatory T Cells Produce IL-10 to Suppress IFN Production and Proliferation of CD8 T Cells. J Immunol. 2005;175:7093-7.

29. Shi Z, Okuno Y, Rifa'l M, Endharti AT, Akane K, Isobe K, et al. Human CD8CXCR3 T cells have the same function as murine CD8CD122 Treg. Eur J Immunol. 2009;39:2106-19.

30. Herndon JM, Stuart PM, Ferguson TA. Peripheral Deletion of Antigen-Specific T Cells Leads to Long-Term Tolerance Mediated by CD8 Cytotoxic Cells. J Immunol. 2005;174:4098-104

31. Dianzani U, Pileri A, Bianchi A, Camponi A, Tamponi G, Massaia M. Biochemical and immunologic abnormalities in peripheral blood $T$ lymphocytes of patients with hemophilia A. Eur J Haematol. 1988:41 Suppl 4:334-40.

32. André $S$, Meslier $Y$, Dimitrov DJ, Repessé $Y$, Kaveri SV, Lacroix-Desmazes $S$, et al. A cellular viewpoint of anti-FVIII immune response in hemophilia $A$. Clin Rev Allergy Immunol. 2009:37 Suppl 2:105-13.

33. Pautard B, D'Oiron R, Te Li Thiao V, Lavend'Homme R, Saint-Remy JM Peerlinck K, et al. Successful immune tolerance induction by FVIII in hemophilia A patients with inhibitor may occur without deletion of FVIII-specific T cells. J Thromb Haemost. 2011;9 Suppl 6:1163-70.

34. Qadura $\mathrm{M}$, Othman $\mathrm{M}$, Waters B, Chegeni R, Walker K, Labelle A, et al. Reduction of the immune response to factor VIII mediated through tolerogenic factor VIII presentation by immature dendritic cells. J Thromb Haemost. 2008;6 Suppl 12:2095-104.

35. Rousset F, Garcia E, Defrance T, Péronne C, Vezzio N, Hsu DH, et al. Interleukin 10 is a potent growth and differentiation factor for activated human B lymphocytes. Proc Natl Acad Sci U S A. 1992;89 Suppl 5:1890-3.

36. Harris DP, Haynes L, Sayles PC, Duso DK, Eaton SM, Lepak NM, et al. Reciprocal regulation of polarized cytokine production by effector $B$ and $T$ cells. Nat Immunol. 2000;1 Suppl 6:475-82.

37. Duddy ME, Alter A, Bar-Or A. Distinct profiles of human B cell effector cytokines: A role in immune regulation? J Immunol. 2004;172 Suppl 6:3422-7.

38. Lund FE. Cytokine-producing B lymphocytes - key regulators of immunity. Curr Opin Immunol. 2008:20 Suppl 3:332-8.

39. Wojciechowski W, Harris DP, Sprague F, Mousseau B, Makris M, Kusser K, et al. Cytokine-producing effector $B$ cells regulate type 2 immunity to $H$. polygyrus. Immunity. 2009;30 Suppl 3:421-33.

40. Oldenburg J, Pavlova A. Genetic risk factors for inhibitors to factors VIII and IX. Haemophilia. 2006;12 Suppl 6:15-22.

41. Lacroix-Desmazes S, Navarrete AM, André S, Bayry J, Kaveri SV, Dasqupta S. Dynamics of factor VIII interactions determine its immunologic fate in hemophilia A. Blood. 2008;112 Suppl 2:240-9.

42. Ghosh K, Shety S. Immune response to FVIII in hemophilia A: an overview of risk factors. Clin Rev Allergy Immunol. 2009;37 Suppl 2:58-66.

43. Pinto $P$, Ghosh $\mathrm{K}$, Shetty $\mathrm{S}$. Immune regulatory gene polymorphisms as predisposing risk factors for the development of factor VIII inhibitors in Indian severe haemophilia A patients. Haemophilia. 2012;18 Suppl 5:794-7.

\section{Submit your next manuscript to BioMed Central and take full advantage of:}

- Convenient online submission

- Thorough peer review

- No space constraints or color figure charges

- Immediate publication on acceptance

- Inclusion in PubMed, CAS, Scopus and Google Scholar

- Research which is freely available for redistribution 